\title{
Suita Zodiak
}

\section{Komposisi Musik untuk String Kuartet dan Trio Woodwind}

OF URBAN SOCIETY'S ARTS

Volume 3 Nomor 1, April 2016: 10-18
Ovan Bagus Jatmika

Program Studi Penciptaan Musik, Fakultas Seni Pertunjukan, Institut Seni Indonesia Yogyakarta

Jln. Parangtritis Km 6,5 Bantul, Yogyakarta 55001

Tlp.085725936960,E-mail: ovanbagusjatmika@gmail.com

\begin{abstract}
ABSTRAK
Zodiak adalah rasi bintang di sepanjang garis ekliptika yang terdiri atas 12 bagian, yaitu Aries, Taurus, Gemini, Cancer, Leo, Virgo, Libra, Scorpio, Sagitarius, Capricorn, Aquarius, dan Pisces. Ke-12 zodiak tersebut memiliki karakter yang berbeda karena dibedakan oleh modus (cardinal, fixed, mutable) dan elemen (api, tanah, udara, air) yang menyusunnya. Fenomena ini, dalam konteks komposisi musik, merupakan hal-hal ekstra musikal. Hal-hal ekstra musikal inilah yang akan diangkat ke dalam komposisi musik programa dengan judul "Suita Zodiak". Komposisi ini disusun dalam 12 gerakan dan disusun dalam 12 tonalitas yang berbeda. Masing-masing gerakan menggambarkan karakter 12 zodiak dari Aries hingga Pisces. Karakter dari ketiga modus yang menyusun zodiak ditransformasi ke musik melalui pembedaan tekstur, sedangkan karakter dari keempat elemen yang menyusun zodiak ditransformasi ke musik melalui pembedaan karakter melodi, suasana musikal, dan pembedaan tempo. Pemaknaan tentang karakter 12 zodiak kemudian dijadikan batasan dalam penciptaan "Suita Zodiak" bersifat arbitrer. Hal ini mengacu pada beberapa karya yang pernah diciptakan sebelumnya, yang sebagian besar menghubungkan karya musik dengan unsur ekstra musikalnya secara arbitrer. Karya ini digarap dalam format string kuartet dan trio woodwind dengan mengembangkan beberapa konsep melodi yang diambil dari thesaurus of scales and melodic pattern.
\end{abstract}

Kata kunci: zodiak, Suita, musik programa, melodic pattern

\begin{abstract}
Zodiac Suite: Music Composition for String Quaertet and Trio Woodwind. Zodiac is the constellations along the ecliptic line consisting of 12 parts, namely Aries, Taurus, Gemini, Cancer, Leo, Virgo, Libra, Scorpio, Sagitarius, Capricorn, Aquarius, and Pisces. The 12 zodiacs have different characters because they are distinguished by the mode (cardinal, fixed, mutable) and elements (fire, earth, air, water) that are arranged them. This phenomenon, in the context of musical composition, is extra-musical things. These extra-musical things will be lifted into musical composition program entitled "Suita Zodiak". This music composition has been worked out in 12 movements and arranged in 12 different tones. Each movement describes the character of the 12 zodiacs from Aries to Pisces. The characters of the three modes setting up the zodiac will be transformed into music through texture distinction; meanwhile the characters of four elements that are creating the zodiac have been transformed into music through the distinction of the melodic character, musical atmosphere, as well as difference in tempo. The meaning of 12 zodiac characters are then used as constraints in the creation of the arbitrary Zodiac Suite. This refers to several masterpieces that had been previously created, most of which relate to musical masterpiece with arbitrary extra-musical element. This artistry has been created in the quartet string and trio woodwind format by developing several melody concepts that are taken from thesaurus of scales and melodic pattern.
\end{abstract}

Keywords: zodiac, Suite, music program, melodic pattern 


\section{Pendahuluan}

Angka 12 cukup akrab dengan dunia musik. Terdapat banyak sekali karya dari komponis musik diatonis yang berhubungan dekat dengan angka 12. Johann Sebastian Bach dengan 24 karya Inventionnya misalnya yang ditulis untuk 12 tangga nada mayor dan 12 tangga nada minor. Niccolo Paganini, seorang pemain biola dari Italia di abad 19 yang juga menulis karya berjudul Caprice untuk permainan solo biola dalam 24 gerakan; serta Arnold Schoenberg, seorang komponis Jerman pada abad 20 yang mengembangkan teknik twelve tone row, juga memanfaatkan angka 12 untuk penamaan teknik komposisi yang dikembangkan Arnold Schoenberg. Kemunculan angka 12 dalam beberapa istilah musik terjadi bukan tanpa sebab. Faktor utama yang menyebabkan angka 12 sering dikaitkan dengan dunia musik dikarenakan nada dalam musik diatonis berjumlah 12 .

Angka 12 bukan hanya berhubungan dekat dengan dunia musik. Dalam ilmu astrologi (ilmu yang menghubungkan antara gerakan benda-benda angkasa dengan nasib manusia), dikenal istilah zodiak, yang juga berjumlah 12, yaitu Aries; Taurus; Gemini; Cancer; Leo; Virgo; Libra; Scorpio; Sagitarius; Capricorn; Aquarius; dan Pisces (Beck 2007). Semua planet, matahari, dan bulan dikarenakan beredar di sepanjang lingkaran ekliptika, otomatis benda-benda tersebut juga berada di antara zodiak. Seseorang akan menyandang tanda zodiaknya berdasarkan kedudukan matahari di dalam zodiak pada tanggal kelahirannya. Misalnya, orang yang lahir pada awal Desember akan berzodiak Sagitarius, karena pada tanggal tersebut matahari berada di wilayah rasi bintang Sagitarius.

Kedua hal tersebut (musik dan astrologi) sama-sama memiliki unsur yang terdiri atas 12 bagian (12 zodiak dalam astrologi serta 12 nada dalam musik diatonis). Berdasarkan kesamaan jumlah tersebut, muncul gagasan untuk menyusun musik programa atau musik yang disusun untuk menggambarkan suatu hal atau cerita tertentu dengan ide zodiak menjadi karya musik instrumental. Karya ini disusun sebagai transformasi jumlah 12 zodiak ke dalam 12 nada dalam musik dengan mengembangkan beberapa konsep melodi yang diambil dari thesaurus of scales and melodic patterns karya Nicholas Slonimsky yang menyusun pola melodi hingga 1330. Alasan penggunaan melodic pattern sebagai tema musik adalah untuk membuka kemungkinan baru dalam menyusun sebuah alur melodi serta memperkaya suasana bunyi dari tangga nada mayor dan minor yang lazim digunakan dalam karya-karya musik tonal (Bintarto 2014).

\section{Seputar Zodiak}

Apabila mengamati pergerakan matahari selama satu tahun peredaran, dapat dibuat sebuah alur atau jalur peredaran yang dikenal dengan istilah garis ekliptika. Zodiak adalah rasi-rasi bintang yang berada di sepanjang garis ekliptika tersebut.

Pada gambar 1 dapat dilihat jalur ekliptika yang dilalui matahari dari arah timur ke barat, dimulai dari titik tengah (titik ekuator) sebagai awal musim semi, bergerak naik 90 derajat sebagai permulaan musim panas, turun 90 derajat kembali ke titik ekuator sehingga memasuki musim gugur, turun lagi hingga kedalaman 90 derajat sebagai permulaan musim dingin, dan kembali lagi ke titik ekuator (0 derajat) sebagai permulaan musim semi (Beck 2007). Siklus semacam ini berlangsung terusmenerus sepanjang tahun yang kemudian dikenal sebagai pergantian musim.

Zodiak terdiri atas 12 bagian dan masingmasing bagian disusun dalam jarak 30 derajat sehingga ke-12 zodiak tersebut akan tersusun secara sama dalam sebuah lingkaran dengan lebar 360 derajat. Apabila garis ekliptika tersebut disusun melingkar, susunan zodiaknya akan terlihat seperti pada gambar 2.

Gerakan matahari melalui jalur ekliptika diawali dari arah timur ke barat, maka urutan

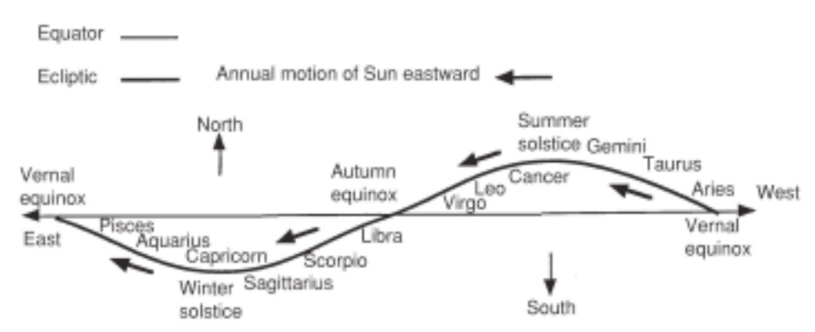

Gambar 1. Jalur ekleptika dan pergantian musim. 


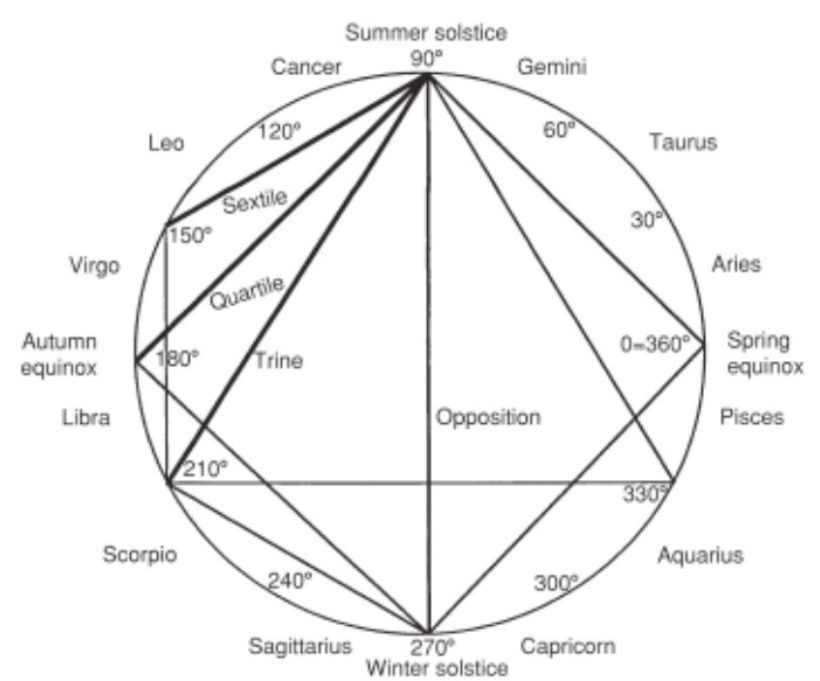

Gambar 2. Susunan zodiak dan pergantian musim

zodiaknya berlawanan dengan arah jarum jam (R.M. Surtihadi 2014).

Zodiak disusun oleh dua unsur yang secara bersamaan membentuk karakter 12 zodiak. Unsur tersebut adalah modus dan elemen. Terdapat tiga modus (cardinal, fixed, mutable) dan empat elemen (api, tanah, udara, air) yang membentuk karakter 12 zodiak. Karakter zodiak ini nantinya akan dijadikan landasan untuk menentukan susana musikal yang diciptakan. Kombinasi dari keduanya membentuk 12 karakter zodiak yang berbeda (Tabel 1, 2, dan 3).

\begin{tabular}{ccc}
\hline No. & Modus & Karakter \\
\hline$(1)$ & $(2)$ & $(3)$ \\
1 & Cardinal & Dinamis \\
2 & Fixed & Statis \\
3 & Mutable & Fleksibel \\
\hline \multicolumn{2}{r}{ Tabel 1. Karakter tiga modus (Beck 2007) }
\end{tabular}

\begin{tabular}{ccc}
\hline No. & Elemen & Karakter \\
\hline$(1)$ & $(2)$ & $(3)$ \\
1 & Api & Kering, maskulin \\
2 & Tanah & Dingin, feminin \\
3 & Udara & Panas, maskulin \\
4 & Air & Basah, feminin \\
\hline
\end{tabular}

Tabel 2. Karakter empat elemen (Beck 2007)

\begin{tabular}{ccccc}
\hline No. & Zodiak & Modus & Elemen & Karakter \\
\hline$(1)$ & $(2)$ & $(3)$ & $(4)$ & $(5)$ \\
1 & Aries & Cardinal & Api & $\begin{array}{c}\text { Dinamis, } \\
\text { kering, } \\
\end{array}$ \\
& & & & maskulin
\end{tabular}

2 Taurus Fixed Tanah Statis, dingin, feminin

3 Gemini Mutable Udara Fleksibel, panas, maskulin

4 Cancer Cardinal Air Dinamis, basah, feminin

5 Leo Fixed Api Statis, kering, maskulin

6 Virgo Mutable Tanah Fleksibel, dingin, feminin

7 Libra Cardinal Udara Dinamis, panas, maskulin

8 Scorpio Fixed Air Statis, basah, feminin

9 Sagitarius Mutable Api Fleksibel, kering, maskulin

10 Capricorn Cardinal Tanah Dinamis, dingin, feminin

11 Aquarius Fixed Udara Statis, panas, maskulin

12 Pisces Mutable Air Fleksibel, basah, feminin

Tabel 3. Karakter 12 zodiak berdasarkan mode dan elemen yang menyusunnya.

\section{Relasi Zodiak dengan Musik}

Berdasar pemaparan singkat tentang zodiak, ditemukan bahwa: (1) 12 zodiak mempunyai karakter yang berbeda disebabkan kombinasi dari tiga modus dan empat elemen. Hal ini dapat disejajarkan dengan 12 nada dalam musik yang masing-masing nadanya mempunyai perbedaan pitch karena adanya perbedaan cent; (2) jumlah zodiak yang terdiri atas 12 bagian memiliki kesamaan dengan 12 nada dalam musik yang dikenal dengan istilah kromatis $(\mathrm{C}, \mathrm{C} \#, \mathrm{D}, \mathrm{D} \#$, E, F, F\#, G, G\#, A, Bb, B). 
Kesamaan zodiak dan musik terdapat dalam hal jumlah, yaitu sama-sama memiliki 12 bagian serta memiliki keparalelan dalam pemaknaan perbedaan karakter dengan perbedaan pitch. Oleh karena itu akan disusun komposisi musik dengan batasan sebagai berikut:

a. Disusun dalam 12 tonalitas yang berbeda.

b. Dirangkai dalam 12 gerakan (movement), serta dikemas dalam bentuk Suita. Suita (partita dalam bahasa Jerman dan Italy, lessons dalam bahasa Inggris, ordres dalam bahasa Perancis) adalah musik instrumental yang ditulis untuk beberapa gerakan. Umumnya disusun antara 3-12 gerakan (Stein, 1962).

\section{Konsep Harmoni}

Harmoni yang digunakan untuk menyusun karya Suita Zodiak adalah harmoni tertian (akor yang disusun dengan interval tiga). Pembahasan tentang harmoni dibagi menjadi dua aspek. Pembahasan yang pertama adalah pembahasan harmoni secara vertikal yang dikenal dengan istilah superimposing. Dalam perspektif vertikal, terdapat tiga kelompok akor, yaitu mayor, minor, dan dominan tujuh (Sandole 1947). Akor diminish dan akor augmented dikelompokkan ke dalam akor dominan (V7b9 untuk akor diminish dan V7\#5 untuk akor augmented). Akor half diminish dimasukkan ke dalam kelompok akor minor (minor7b5). Aturan penyusunannya lihat tabel 4.

Angka 1, 3, 5, 7, 9, 11, dan 13 mewakili nada yang disusun secara vertikal ke atas. Angka 1 adalah nada root sebagai nada dasar dari akor yang akan disusun. Misal akan disusun akor $\mathrm{C}$ mayor, berarti harus disusun nada $1(\mathrm{C}), 3(\mathrm{E})$, dan $5(\mathrm{G})$.

\begin{tabular}{ccc}
\hline Mayor & Minor & Dominan \\
\hline 1 & 1 & 1 \\
3 & -3 & 3 \\
$-5 / 5 /+5$ & $-5 / 5$ & $-5 / 5 /+5$ \\
7 & $-7 / 7$ & -7 \\
$9 /+9$ & $-9 / 9$ & $-9 / 9 /+9$ \\
+11 & $11 /+11$ & $11 /+11$ \\
13 & 13 & $-13 / 13$ \\
\hline
\end{tabular}

Tabel 4. Aturan penyusunan akor
Sementara nada 7(B), 9(D), +11(F\#), dan 13(A) digunakan sebagai superimposing. Fungsi dari nadanada superimposing adalah untuk menambah tensi atau warna pada akor dasar yang telah tersusun. Cara yang sama berlaku juga untuk akor minor dan dominan. Aturan penyusunan nadanya seperti pada kolom di atas.

Aspek yang kedua adalah pembahasan harmoni secara horizontal yang lebih umum dikenal dengan istilah progresi (Russo, 1961: 10). Pada tabel di bawah ini, akor dibagi ke dalam tiga kolom (X, Y, dan Z). Akor pada kolom X dapat bergerak ke akor pada kolom Y. Sementara akor pada kolom Y dapat bergerak ke akor di kolom Z. Gerakannya tersebut tidak berlaku sebaliknya. Akor pada kolom Y tidak dapat bergerak ke akor pada kolom $X$, begitu juga akor pada kolom $\mathrm{Z}$ tidak dapat bergerak ke akor di kolom Y. Apabila gerakan akor sudah sampai pada kolom Z, maka akor terakhir (akor yang terdapat pada kolom Z) dapat dianggap sebagai akor pada kolom X sehingga pergerakan akornya dapat berputar terus-menerus membentuk sebuah alur progresi. Alur gerakan akor dapat dilihat pada tabel 5 .

\begin{tabular}{lll}
\hline $\begin{array}{c}\text { X (umumnya } \\
\text { terdapat pada awal } \\
\text { birama) }\end{array}$ & $\begin{array}{c}\text { Y (umumnya ter- } \\
\text { dapat pada akhir } \\
\text { birama }\end{array}$ & $\begin{array}{c}\text { Z (umum- } \\
\text { nya terdapat } \\
\text { pada awal } \\
\text { birama) }\end{array}$ \\
\hline $\begin{array}{l}\text { Dmin7 (ke semua } \\
\text { akor pada kolom Y) }\end{array}$ & $\begin{array}{l}\text { G7 (ke semua akor } \\
\text { pada kolom Z) }\end{array}$ & $\begin{array}{l}\text { C (Emin7, } \\
\text { Amin7) }\end{array}$ \\
$\begin{array}{l}\text { Dmin (ke semua akor } \\
\text { pada kolom Y) }\end{array}$ & $\begin{array}{l}\text { Db7 (ke semua akor } \\
\text { pada kolom Z) }\end{array}$ & Cmin \\
F (ke semua akor pada & Bb9 (ke-3 akor per- & Cmin7 \\
kolom Y) & tama pada kolom Z) & Cmin7b5 \\
$\begin{array}{l}\text { Fmin (ke-4 akor } \\
\text { pertama pada kolom }\end{array}$ & $\begin{array}{l}\text { Fmin7 (ke semua akor } \\
\text { pada kolom Z) }\end{array}$ & Cdim7, C7 \\
Y) & Fmin (ke semua akor & \\
$\begin{array}{l}\text { Dmin7b5 (ke-4 akor } \\
\text { pertama pada kolom }\end{array}$ & pada kolom Z) & \\
Y) & akor pertama pada & \\
Fmin7 (ke-3 akor per- & kolom Z) & \\
tama pada kolom Y) & & \\
Ab (ke-2 akor pertama & \\
pada kolom Y) & \\
Abmin (ke-2 akor per- \\
tama pada kolom Y) \\
$\begin{array}{l}\text { Abmin7 (ke-2 akor } \\
\text { pertama pada kolom }\end{array}$ & \\
Y) & & \\
\hline
\end{tabular}

Tabel 5. Alur progresi 


\section{Thesaurus of Scales and Melodic Pattern}

Thesaurus of scales and melodic pattern adalah sejenis kamus musik tentang melodic pattern yang disusun secara sistematis hingga 1330 kombinasi. Teknik penyusunannya dilakukan dengan cara menentukan principle tones ${ }^{5}$ terlebih dahulu, kemudian disusun dengan menyisipkan nada tambahan menggunakan teknik interpolasi (nada di antara interval pokok dalam rangkaian principle tones), ultrapolasi (nada dengan register yang lebih tinggi daripada interval pokok dalam rangkaian principle tones), infrapolasi (nada dengan register yang lebih rendah dari interval pokok dalam rangkaian principle tones), dan kombinasi ketiganya (Slonimsky, 1947:ii). Penggunaan nada tambahan tidak hanya sebatas 1 nada di antara principle tone, tetapi dapat menggunakan dua hingga tiga nada sisipan (Gambar 3).

Terdapat sebelas interval yang dapat digunakan untuk menyusun principle tones dengan teknik pengolahan yang sama seperti pada gambar di atas, yaitu semitonel minor second (pattern no. 637-657), whole tonel major second (pattern no. 569-636), sesquitonel minor third (pattern no. 392568), ditonel major third (pattern no. 181-391), diatessaron/ perfect fourth (pattern no. 826-920), tritonel augmented fourth (pattern no. 1-180), diapentel perfect fifth (pattern no. 926-1025), quadritonel minor sixth (pattern no. 658-736), sesquiquadritonel major sixth (pattern no. 737-805), quinquetonel minor seventh (pattern no. 806-825), dan sesquiquinquetonel major seventh (pattern no. 1026-1033). Interval dengan loncatan jauh (empat, lima, hingga tujuh) dapat disesuaikan registernya berdasarkan batas kemampuan instrumen, sehingga
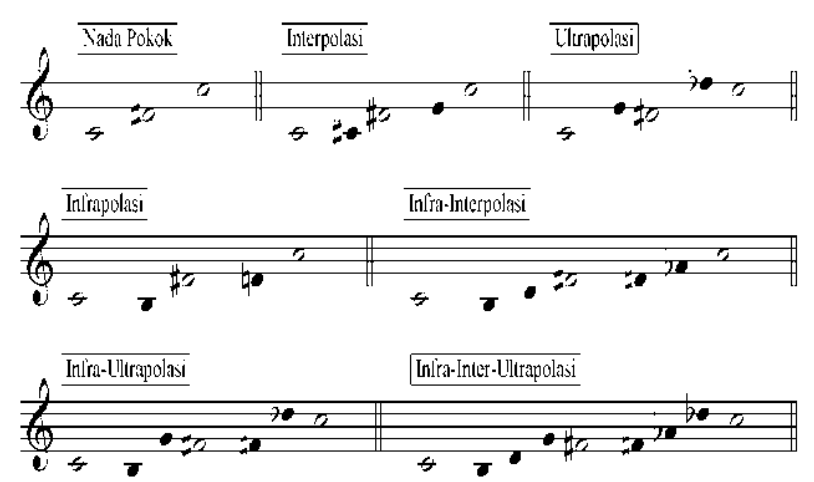

Gambar 3. Penggunaan nada tambahan tetap dapat dimainkan dengan leluasa tanpa keluar dari pattern yang telah ditentukan.

Penggunaan nada sisipan hingga tiga nada di antara principle tone menjadi faktor utama banyaknya kombinasi melodic pattern yang dapat disusun dari sebelas interval pokok seperti yang telah dijelaskan di atas. Tangga nada yang telah disusun seperti notasi di atas kemudian diharmonisasi dengan dua cara. Cara yang pertama adalah dengan akor trinada mayor, sedangkan yang berikutnya adalah dengan harmonisasi akor dominan tujuh. Penggunaan akor trinada minor dalam rangkaian melodic pattern memiliki kaidah yang sama dengan aturan yang digunakan pada harmonisasi akor trinada mayor. Penjelasannya adalah sebagai berikut:

a. Harmonisasi akor trinada mayor

Dalam menyusun harmonisasi trinada mayor, teori ini hanya menggunakan posisi dasar (root sebagai bas) dan akornya disusun dalam harmoni tertutup (close harmony). Sementara itu, root, ters, dan fifth dapat muncul di melodi suara atas (sopran). Figurnya dapat disimbolkan sebagai 8, 3, dan 5 . Apabila melodi naik, diatonik atau kromatik maka penyusunan harmoni secara berturut-turut akan berubah dari oktaf (8) ke tertian (3), ke quintan (5), ke oktaf (8). Jika melodi turun, penyusunannya adalah kebalikan dari arah naik. Jika melodi statis, penyusunan harmoninya bebas (Slonimsky 1947). b. Harmonisasi akor dominan tujuh

Harmonisasi akor dominan tujuh hanya disusun pada principle tones. Terdapat tiga macam akor dominan yang digunakan, yaitu akor tujuh (dominan tujuh/V7), akor dominan sembilan (dapat dimunculkan dengan menggunakan alterasi seperti V7b9 atau V7\#9), dan akor whole tone seperti akor V7\#5, V7b5 atau V7\#11, V9\#5, serta V9b5 atau V9\#11 (Slonimsky 1947). Nada kelima dapat dihilangkan dalam susunan close voicing atau aturan pemyusunan harmoni yang menempatkan nada akor dalam jarak yang berdekatan.

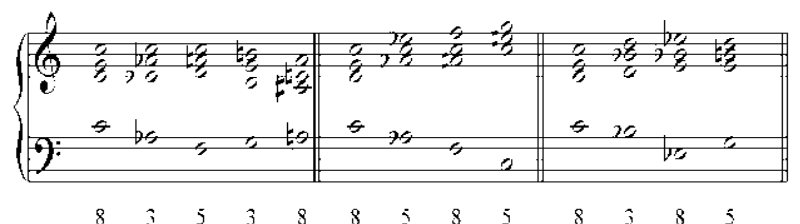

Gambar 4. Harmonisasi akor trinada mayor 

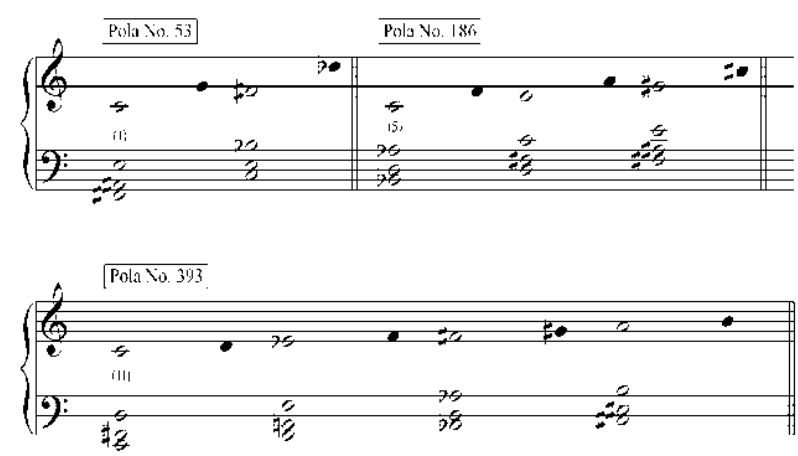

Gambar 5. Harmonisasi akor dominan tujuh

Konsep penyusunan melodic pattern dan cara penggunaan akor seperti penjelasan di atas dijadikan landasan dalam menyusun motif atau tema musik yang dikembangkan menggunakan prosedur dasar pengembangan komposisi seperti inversi, retrogresi, augmentasi, diminusi, dan lain sebagainya. Pada aspek harmoni, dilakukan sedikit modifikasi dengan menyusun akor secara arpegio pada suara bawah sebagai ostinato, sementara suara atas memainkan melodi sesuai dengan pattern yang dipilih. Harmoni yang tersusun dengan cara ini akan membentuk alur kontrapung bersama dengan melodic pattern sebagai kesatuan dalam sebuah tema musikal.

\section{Proses Penyusunan Karya}

Seperti telah disebutkan pada bagian pendahuluan, relasi antara unsur ekstra musikal dengan unsur musik dilakukan secara arbitrer. Dalam hal ini, karakter dari ketiga modus yang menyusun zodiak ditransformasi ke musik melalui pembedaan tekstur, sedangkan karakter dari keempat elemen yang menyusun zodiak ditransformasi ke musik melalui pembedaan karakter melodi, suasana musikal, serta pembedaan tempo (Tabel 6, 7, dan 8)

\begin{tabular}{cccc}
\hline No. & Modus & Karakter & Transformasi ke musik \\
\hline 1 & Cardinal & Dinamis & Polifoni \\
2 & Fixed & Statis & Homofoni \\
3 & Mutable & Fleksibel & $\begin{array}{l}\text { Bisa polifoni, homo- } \\
\text { foni, atau gabungan }\end{array}$ \\
\hline
\end{tabular}

Tabel 6. Karakter tiga modus dan transformasinya ke dalam musik

\begin{tabular}{cccc}
\hline No. & Elemen & Karakter & Transformasi ke musik \\
\hline 1 & Api & $\begin{array}{c}\text { Kering, } \\
\text { maskulin }\end{array}$ & Ritmikal, tempo cepat \\
2 & Tanah & $\begin{array}{c}\text { Dingin, } \\
\text { feminin } \\
\text { Panas, } \\
3\end{array}$ & Melodius, tempo lambat \\
Udara & $\begin{array}{c}\text { Gaskulin } \\
\text { Basah, } \\
\text { feminin }\end{array}$ & Tenang, tempo lambat \\
\hline & Air & Tepat \\
\hline
\end{tabular}

Tabel 7. Karakter empat elemen dan transformasinya ke dalam musik

\begin{tabular}{|c|c|c|c|}
\hline No. & Zodiak & Karakter & $\begin{array}{c}\text { Transformasi ke } \\
\text { musik }\end{array}$ \\
\hline 1 & Aries & $\begin{array}{l}\text { Kering, maskulin, } \\
\text { dinamis }\end{array}$ & $\begin{array}{l}\text { Ritmikal, tempo } \\
\text { cepat, polifoni }\end{array}$ \\
\hline 2 & Taurus & $\begin{array}{l}\text { Dingin, feminin, } \\
\text { statis }\end{array}$ & $\begin{array}{l}\text { Melodius, tempo } \\
\text { lambat, homofoni }\end{array}$ \\
\hline 3 & Gemini & $\begin{array}{c}\text { Panas, maskulin, } \\
\text { fleksibel }\end{array}$ & $\begin{array}{c}\text { Gaduh, tempo cepat, } \\
\text { homofoni }\end{array}$ \\
\hline 4 & Cancer & $\begin{array}{l}\text { Basah, feminin, } \\
\text { dinamis }\end{array}$ & $\begin{array}{l}\text { Tenang, tempo } \\
\text { lambat, polifoni }\end{array}$ \\
\hline 5 & Leo & $\begin{array}{l}\text { Kering, maskulin, } \\
\text { statis }\end{array}$ & $\begin{array}{l}\text { Ritmikal, tempo } \\
\text { cepat, homofoni }\end{array}$ \\
\hline 6 & Virgo & $\begin{array}{l}\text { Dingin, feminin, } \\
\text { fleksibel }\end{array}$ & $\begin{array}{l}\text { Melodius, tempo } \\
\text { lambat, homofoni }\end{array}$ \\
\hline 7 & Libra & $\begin{array}{l}\text { Panas, maskulin, } \\
\text { dinamis }\end{array}$ & $\begin{array}{c}\text { Gaduh, tempo cepat, } \\
\text { polifoni }\end{array}$ \\
\hline 8 & Scorpio & $\begin{array}{c}\text { Basah, feminin, } \\
\text { statis }\end{array}$ & $\begin{array}{l}\text { Tenang, tempo } \\
\text { lambat, homofoni }\end{array}$ \\
\hline 9 & Sagitarius & $\begin{array}{c}\text { Kering, maskulin, } \\
\text { fleksibel }\end{array}$ & $\begin{array}{c}\text { Ritmikal, tempo cepat, } \\
\text { gabungan polifoni dan } \\
\text { homofoni }\end{array}$ \\
\hline 10 & Capricorn & $\begin{array}{l}\text { Dingin, feminin, } \\
\text { dinamis }\end{array}$ & $\begin{array}{l}\text { Melodius, tempo } \\
\text { lambat, polifoni }\end{array}$ \\
\hline (1) & (2) & (3) & $(4)$ \\
\hline 11 & Aquarius & $\begin{array}{l}\text { Panas, maskulin, } \\
\text { statis }\end{array}$ & $\begin{array}{c}\text { Gaduh, tempo cepat, } \\
\text { homofoni }\end{array}$ \\
\hline 12 & Pisces & $\begin{array}{l}\text { Basah, feminin, } \\
\text { fleksibel }\end{array}$ & $\begin{array}{l}\text { Tenang, tempo } \\
\text { lambat, homofoni }\end{array}$ \\
\hline
\end{tabular}

Tabel 8. Karakter 12 zodiak

Rancangan dasar tersebut kemudian diaplikasikan ke dalam ciptaan sesungguhnya. Sampai tahap ini, musik ditulis dalam skor piano. Penulis tidak akan menjelaskan proses penciptaan karya secara utuh, namun hanya menjelaskan proses penciptaan salah satu bagian karya, yaitu Aries.

Aries disusun dalam bentuk fuga empat suara. Fuga adalah karya musik polifoni untuk tiga suara atau lebih, dikembangkan dari motif yang disebut subject dan diolah dengan teknik kontrapung. Terdapat delapan tahapan dalam proses penyusunan fuga: 
a. Menyusun subject

Subject disusun sepanjang dua setengah birama dalam $\mathrm{Bb}$ mayor.

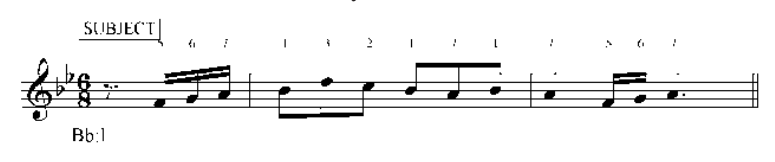

Subject tersebut lantas diimitasi pada tingkat $\mathrm{V}$ (F mayor) dari nada dasar (Bb mayor) dan dimunculkan pada register suara yang berbeda. Imitasi ini disebut answer. Answer yang tersusun akan terlihat seperti notasi berikut ini:

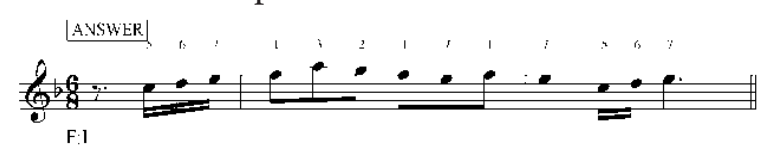

b. Menyusun counter subject

Counter subject disusun untuk mengisi bagian kosong ketika answer muncul pada akhir subject. Disebut counter subject jika bagian ini kembali dimunculkan berkali-kali dengan bentuk yang sama. Tetapi jika hanya sekali dimunculkan, hanya disebut counterpoint. Contohnya dapat dilihat pada notasi berikut ini. Subject (S), answer (A), dan counter subject (CS).

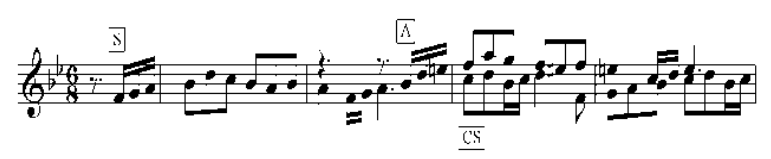

c. Menempatkan subject beserta answer pada alto, sopran, bas dan tenor untuk membentuk bagian eksposisi pertama

Subject muncul di alto pada birama pertama, dan diikuti answer dengan modulasi ke tingkat lima di register sopran. Counter subject muncul di alto hingga birama keempat mengiringi answer yang muncul di register sopran. Subject kembali muncul pada birama kelima di bas, dan diikuti answer dengan modulasi ke tingkat lima di tenor, disusul munculnya counter subject di bas hingga akhir bagian eksposisi pertama. Sementara itu, di suara atas, yaitu sopran dan alto terdapat counterpoint yang dimulai dari birama kelima hingga akhir bagian eksposisi pertama seperti pada notasi berikut ini:

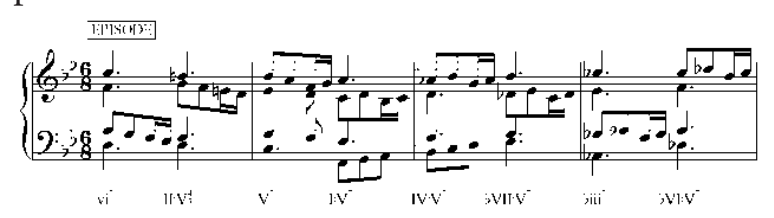

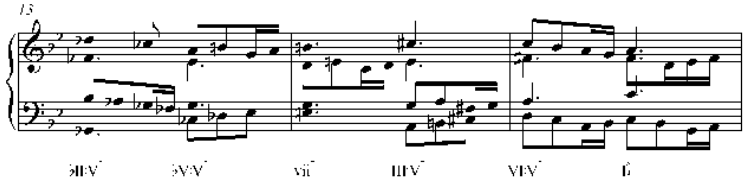

d. Menyusun episode

Episode terdiri dari tujuh birama, dimulai dari birama 9 hingga birama lima belas. Episode pada bagian ini berfungsi sebagai pengantar dari eksposisi bagian pertama yang berakhir di F mayor, menuju eksposisi di bagian berikutnya yang dimulai dari $G$ minor. Notasi berikut ini adalah episode pertama Suita Zodiak Aries yang berupa susunan kontrapung bebas. Konsep penyusunan kontrapung pada bagian ini didasari dengan landasan gerakan harmoni dalam tingkat lima (circle of fifth).

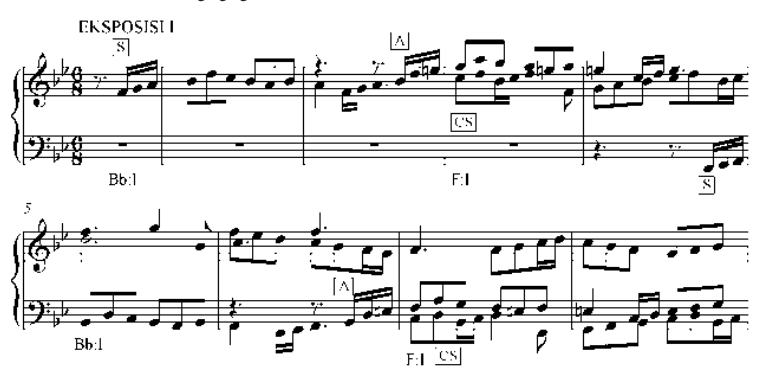

e. Menyusun subject pada beberapa suara untuk menyusun bagian eksposisi II (middle section).

Bagian ini terdiri dari lima belas birama, dimulai dari birama enam belas hingga birama tiga puluh. Pada awal bagian middle section, subject dimainkan dalam G minor di alto, kemudian dijawab di tingkat lima. Answer selanjutnya diimitasi pada register sopran diikuti subject pada register bas. Subject yang terdapat pada register bas lantas diikuti answer pada register alto dengan penyusunan stretto (ditempatkan secara bersusun sebelum akhir bagian subject). Bagian akhir eksposisi II ditutup dengan memunculkan subject secara bergantian pada register bas, sopran, dan alto. Counter subject muncul setiap kali subject atau answer dimainkan, namun dengan sedikit modifikasi pada aspek ritmis serta kontur melodi.

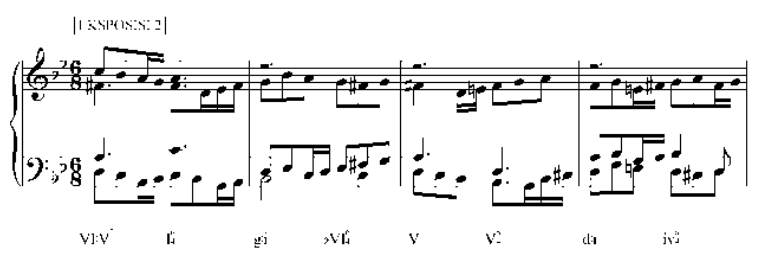



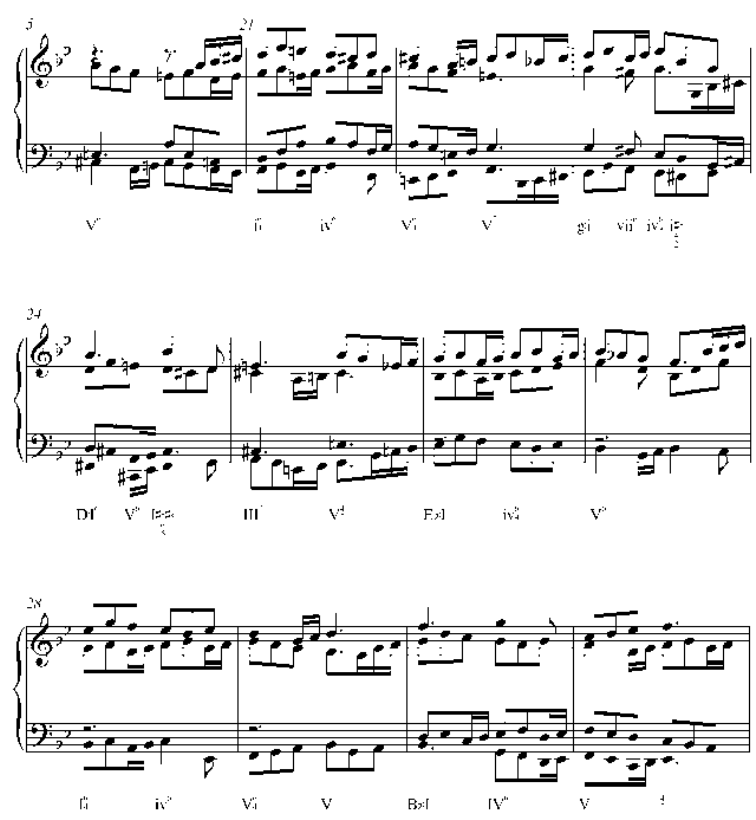

f. Menyusun episode untuk menuju eksposisi III (concluding section).

Episode kedua ditulis sepanjang tujuh birama, dimulai dari birama tiga puluh satu, dan berakhir di birama tiga puluh tujuh. Berbeda dengan episode pada bagian sebelumnya yang berfungsi sebagai jembatan dari F mayor menuju $\mathrm{G}$ minor, episode pada bagian ini berfungsi sebagai transisi dari bagian eksposisi II yang berakhir pada Eb mayor menuju bagian eksposisi III yang kembali dimainkan dalam Bb mayor. Materi yang digunakan pada bagian ini diambil dari melodic pattern no. 39 dan disusun dalam kontrapung dua suara.
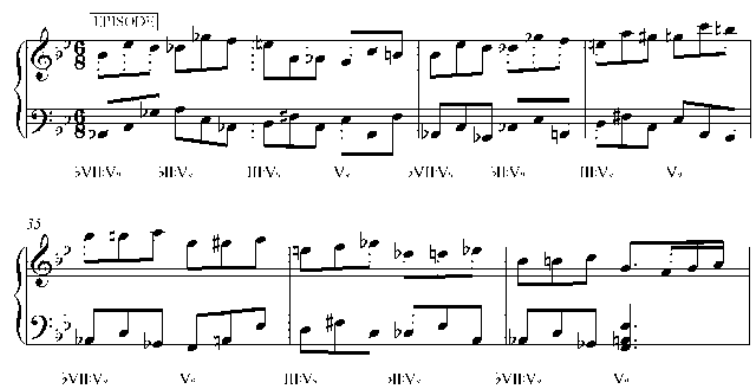

g. Memunculkan kembali subject untuk menyusun eksposisi III (concluding section).

Subject pada eksposisi III disusun secara stretto dalam Bb mayor. Subject muncul pertama kali pada sopran, lalu tenor, bas, dan terakhir muncul di alto yang diikuti oleh coda. Berikut ini adalah notasi bagian eksposisi III yang disusun sepanjang lima birama dalam Bb mayor.
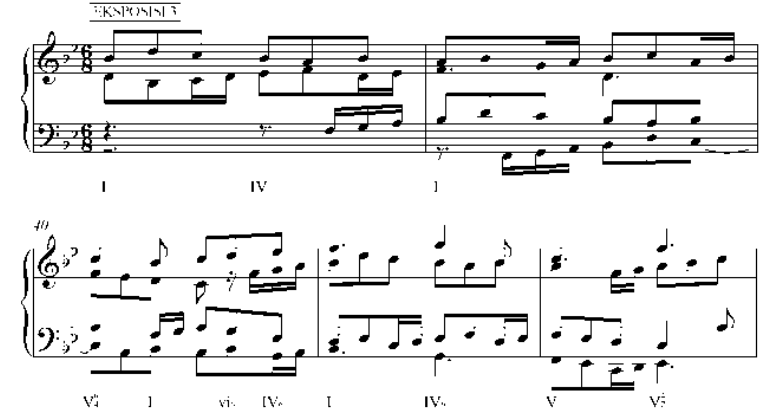

h. Menyusun coda

Coda disusun sepanjang enam birama serta berisi progresi akor diatonis yang berakhir pada akor tingkat I. Coda pada musik fuga umumnya disusun di atas pedal bas pada tonika. Namun, aturan tersebut dengan sengaja diabaikan pada karya Suita Zodiak Aries.

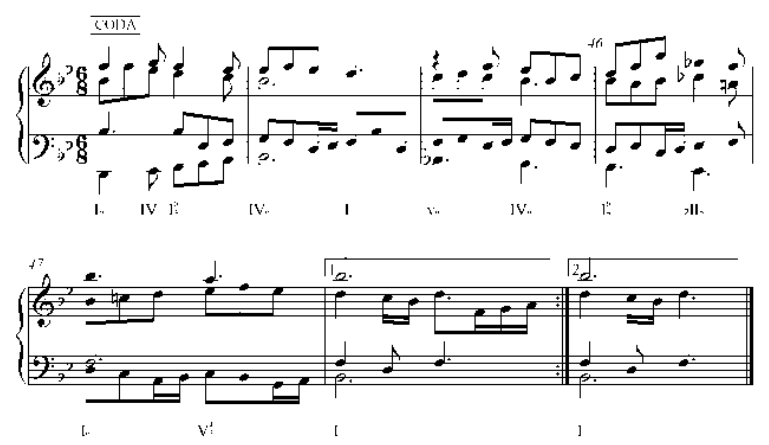

\section{Simpulan}

Proses penciptaan Suita Zodiak seperti yang telah dijelaskan melahirkan beberapa kesimpulan sebagai berikut: (1) Korelasi antara unsur ekstra musikal dengan unsur musikal dapat disusun dengan cara mencari keparalelan yang logis antara keduanya, walaupun pemaknaannya seringkali bersifat arbitrer. Hal ini terlihat misalnya pada penganalogian unsur ekstra musikal ke dalam musik abad 16 hingga 19, seperti penggambaran surga dengan nada tinggi, penggambaran gerak jatuh dengan tangga nada kromatis turun, penggambaran iblis dengan interval tritonus, dan sebagainya; (2) walaupun musik programa mengandung muatan unsur ekstra musikal yang diekspresikan melalui media bunyi, pada proses penciptaan karya tetap diperlukan pemahaman yang mendalam tentang aspek teknis kompositoris, karena tanpa pemahaman yang baik dalam hal teknis kompositoris pengaplikasian ide ke dalam karya tidak akan bisa berjalan maksimal. 


\section{Ucapan Terima Kasih}

Ucapan terima kasih disampaikan kepada (1) Dr. Royke B. Koapaha atas saran dan masukannya yang sangat detail; (2) Bapak Slamet Abdul Syukur (almarhum) atas kritik dan sarannya yang sangat membangun; (3) Teman-teman pemain: Didit, Erik, Tamtomo, Rama, Boris, Dwi, dan Angga yang telah membantu memainkan karya ini.

\section{Kepustakaan}

Beck, R., 2007. A Brief History of Ancient Astrologi.

Victoria: Blackwell Publishing.

Bintarto, A.G., 2014. "Aspek Olah Vokal Musik
Klasik Barat Pada Musik Populer”. Journal Of Urbarn Society's Arts, 1(1), p.44.

R.M. Surtihadi, 2014. "Instrumen Musik Barat dan Gamelan Jawa dalam Iringan". Journal Of Urbarn Society's Arts, 1(1), p.27.

Russo, W., 1961. Composing for the Jazz Orchestra, Chicago: The University of Chicago Press.

Sandole, A., 1947. Beginner's Method for Jazz Improvisation. In Rambling Way.

Slonimsky, N., 1947. Thesaurus os Scales and Melodic Pattern. New York: Charles Scribner's Sons.

Stein, L., 1962. Structure and Style: The Study and Analysis of Musical Forms. New Jersey: Summy-Birchard Music. 